\title{
ANALISIS KAPLAN MEIER TERHADAP PERBAIKAN KLINIS BATUK PADA PASIEN PNEUMONIA ANAK YANG DIBERIKAN TERAPI TAMBAHAN VITAMIN D
}

\section{Kaplan Meier's Analysis of Clinical Improvement of Cough in Child Pneumonia Patient's that Given with Additional Vitamin D Therapy}

\section{Arief Rafsanjani ${ }^{\text {** }}$ \\ Endang Darmawan ${ }^{2}$}

Nurcholid Umam

Kurniawan ${ }^{3}$

Tri Puspita Yuliana ${ }^{4}$

Aditya Noviadi

Rakhmatullah ${ }^{5}$

*IUniversitas Hamzanwadi, Selong, Nusa Tenggara Barat, Indonesia

2Universitas Ahmad Dahlan, Yogyakarta, DIY, Indonesia

3 Universitas Ahmad Dahlan, Yogyakarta, DIY, Indonesia

4Universitas Hamzanwadi, Selong, Nusa Tenggara Barat, Indonesia

${ }^{5}$ Stikes Borneo Lestari Banjarbaru, Kalimantan Selatan, Indonesia

*email:

Ariefrafsanjani21@gmail.com

Kata Kunci:

Pneumonia

Vitamin D

Batuk

Kaplan Meier

Keywords:

Pneumonia

Vitamin D

Cough

Kaplan Meier

\begin{abstract}
Abstrak
Pneumonia merupakan penyebab utama kematian pada anak-anak usia di bawah 5 tahun dan berkontribusi hingga 14\% dari total kematian anak secara global pada tahun 2013. Pneumonia merupakan suatu peradangan paru yang disebabkan oleh mikroorganisme seperti bakteri, virus, jamur, parasit dan menyerang parenkim paru. Angka kesembuhan pneumonia setelah mendapatkan terapi antibiotik cukup tinggi, tetapi angka mortalitas yang disebabkan infeksi pneumonia juga masih tinggi, oleh sebab itu perlu ada upaya dalam penambahan terapi untuk memperbaiki outcome klinis pasien. Vitamin D di ketahui berperan dalam fungsi pertahanan tubuh, baik dalam imunitas alamiah dan adaptif serta berperan dalam pertahanan tubuh pada kasus infeksi, alergi, keganasan, dan autoimun. Penelitian ini adalah penelitian eksperimental double blind randomised clinical trial yang di analisis menggunakan kaplan meier. Subyek penelitian adalah pasien anak usia 6 bulan sampai 18 tahun yang terbagi menjadi dua kelompok perlakuan, yaitu kelompok perlakuan $(n=35)$ dan kelompok kontrol $(n=35)$. Kelompok perlakuan mendapatkan vitamin D, sedangkan kelompok kontrol sebagai plasebo. Data yang diambil meliputi hasil pemeriksaan klinis batuk pasien Hasil penelitian ini menunjukkan pemberian vitamin $D$ efektif dalam mempercepat penurunan frekuensi batuk pasien anak yang terinfeksi pneumonia.
\end{abstract}

\begin{abstract}
Pneumonia is the leading cause of death in children under 5 years of age and contributed up to $14 \%$ of total global child deaths in 2013. Pneumonia is an inflammation of the lungs caused by microorganisms such as bacteria, viruses, fungi, parasites, and attacks the lung parenchyma. The cure rate for pneumonia after receiving antibiotic therapy is quite high, but the mortality rate due to pneumonia infection is still high, therefore there needs to be an effort to add therapy to improve patient clinical outcomes. Vitamin D plays a role in the body's defense function, both in natural and adaptive immunity, and plays a role in the body's defense in cases of infection, malignancy, and autoimmunity. This study was an experimental double-blind randomized clinical trial that was analyzed using Kaplan Meier. The research subjects were children aged 6 months to 18 years who were divided into two treatment groups, namely the treatment group $(n=35)$ and the control group $(n=35)$. The treatment group received vitamin $D$, while the control group a placebo. The data taken included the results of clinical studies of patients. The results of this study indicate that vitamin $D$ is effective in accelerating the cough frequency of patients infected with pneumonia.
\end{abstract}




\section{PENDAHULUAN}

Pneumonia merupakan penyakit infeksi akut yang mengenai parenkim paru, distal dari bronkiolus terminalis yang mencakup bronkiolus respiratorius dan alveoli, serta menimbulkan konsolidasi jaringan paru dan gangguan pertukaran gas (Dahlan, 2014). Menurut World Health Organization (2017) 15\% dari kematian anak dibawah 5 tahun di sebabkan oleh pneumonia dan berdasarkan hasil Riset Kesehatan Dasar (Riskesdas) tahun 2013 menunjukkan angka prevalensi pneumonia pada balita sangat tinggi, yaitu 4,5 per 100 balita. Pada tahun 2016, pneumonia menjadi penyebab utama kematian pada anak-anak di seluruh dunia, hampir membunuh 2.500 anak setiap harinya. Sebagian besar penderita pneumonia berusia kurang dari 2 tahun dan kejadian paling banyak terjadi di Asia Selatan dan Afrika subsahara (Unicef, 2017). Tingkat kematian anak-anak umur di bawah 5 tahun yang disebabkan oleh pneumonia di Eropa mencapai I2\% dari 263.000 kasus kematian, sekitar 12\% dari 439.000 kasus kematian di wilayah Amerika, sekitar 13\% dari 1.020 .000 untuk wilayah Pasific Barat, sekitar 21\% dari 1.409 juta kasus kematian untuk wilayah Mediterania Timur, sekitar 19\% dari 3.070 juta kematian di kawasan Asia Tenggara dan sekitar $21 \%$ dari 4.396 juta kasus kematian untuk wilayah Afrika (Rudan et al., 2008).

Pneumonia menjadi penyebab kematian kedua pada balita usia I-4 tahun setelah diare dengan angka kematian mencapai 196.579 (I5,5\%) pada tahun 2007 atau rata-rata 83 balita meninggal tiap hari akibat pneumonia (Riskesdas, 2007). Lima provinsi yang memiliki prevalensi pneumonia tertinggi pada pasien balita yaitu Nusa Tenggara Barat (6,38\%), Kepulauan Bangka Belitung (6,05\%), Kalimantan Selatan (5,53\%), Sulawesi Tengah (5,19\%), dan Sulawesi Barat (4,88). Provinsi Yogyakarta sendiri termasuk peringkat ke 9 dari 33 provinsi yang ada di Indonesia dengan prevalensi sekitar 4,32\% (Kemenkes RI, 2017). Kabupaten Bantul pada tahun 2015 melaporkan sebanyak 1004 kasus balita pneumonia dan turun pada tahun 2016 menjadi 744 kasus dengan 3 kasus kematian pada bayi (Dinkes Bantul, 2017).

Vitamin $D$ merupakan hormon steroid yang berperan penting pada pengaturan kadar kalsium dan fosfat serum, dan mineralisasi tulang (Feldman D et al., 20I4). Vitamin $D$ diketahui berperan dalam fungsi pertahanan tubuh pada kasus infeksi, alergi, keganasan, dan autoimun (Sankar et al., 20I6). Vitamin D berasal dari kulit yang terpapar sinar matahari pagi dan dari diet di metabolisme di hati menjadi $25(\mathrm{OH})-\mathrm{D} .25(\mathrm{OH})-\mathrm{D}$ digunakan untuk menentukan status vitamin $D$ pasien, kemudian $25(\mathrm{OH})-\mathrm{D}$ dimetabolisme di ginjal dengan bantuan enzim 25-hidroksivitamin D-lalfa-hidroksilase (CYP27BI) menjadi bentuk aktif yaitu I, 25dihidroksivitami D (Dhungel \& Alam, 20I5).

Atas dasar latar belakang di atas disertai tingginya angka mortalitas yang disebabkan oleh pneumonia mendorong peneliti ingin mengetahui peranan vitamin D terhadap perbaikan kondisi klinis batuk pada pasien anak yang terinfeksi pneumonia menggunakan analisis kaplan meier.

\section{METODOLOGI}

\section{Alat dan bahan}

Penelitian ini menggunakan obat vitamin D (D3-VIT®, $400 \mathrm{UI} / 5 \mathrm{ml}$ yang diperoleh dari Industri Farmasi PT Gracia Pharmindo). Dosis obat yang digunakan berbeda-beda tergantung dari usia pasien, yaitu 6-12 bulan mendapatkan dosis 400 UI sekali sehari dan usia 12 bulan - 18 tahun mendapatkan dosis 600 UI sekali sehari pada jam yang sama.

\section{Metode Penelitian.}

Desain penelitian yang digunakan pada penelitian ini adalah eksperimental Double Blind Randomised Clinical Trial dengan subyek penelitian pasien anak usia 6 bulan sampai 18 tahun yang menderita pneumonia (ICD-I0:II8.9) di Rumah Sakit PKU Muhammadyah Bantul. Pengambilan data dilakukan pada bulan maretjuli 2019 dan mendapatkan 70 pasien yang masuk dalam kriteria inklusi. 70 pasien tersebut terbagi 
menjadi dua kelompok, yaitu kelompok perlakuan mendapatkan vitamin $D(n-35)$ dan kelompok control mendapatkan placebo $(n=35)$. Adapun kriteri ainklusi pada penelitian ini adalah pasien anak usia 6 bulan sampai 18 tahun yang terdiagnosa pneumonia, wali pasien bersedia mengisi lembar informed consent dan pasien mendapatkan resep vitamin D. kriteria eksklusi adalah wali pasien tidak bersedia mengisi informed consent, pasien tidak mendapatkan resep vitamin $D$, pasie pulang paksa atau di rujuk ke rumah sakit yang lain. Pasien yang masuk ke dalam kriteria inklusi selanjutnya dilakukan visite oleh peneliti setiap hari selama perawatan dan mengambil data penelitian

\section{HASIL DAN PEMBAHASAN}

A. Karakteristik pasien

Karakteristik jenis kelamin pada penelitian ini terdiri dari 35 (50\%) pasien anak laki-laki dan 35 (50\%) pasien anak perempuan. Menurut profil kesehatan tahun 2015, kota Yogyakarta melaporkan bahwa pada tahun 2014 kasus pneumonia pada balita laki-laki lebih banyak dibandingkan perempuan yaitu 290 pasien laki-laki dan 255 pasien perempuan (Dinkes Bantul, 2017). Hasil penelitian deskriptif retrospektif yang dilakukan oleh Kaunang et al., (2016) pada pasien pneumonia anak di Manado dengan jumlah sampel I 58 pasien, menyatakan bahwa kejadian pneumonia pada anak laki-laki sebesar $55,7 \%$ dan pada anak perempuan sebesar $(44,3 \%)$.

Berikut merupakan grafik hasil analisis kaplan meier pada pasien anak yang terinfeksi pneumonia di Rumah Sakit PKU Muhammadyah Bantul setelah di berikan vitamin $\mathrm{D}$ dan plasebo. Hasil analisis kaplan meier bisa dilihat pada gambar I.

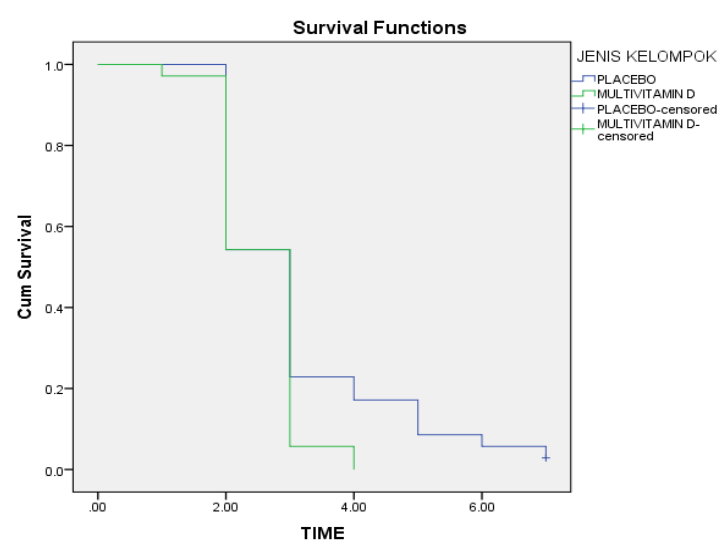

Gambar I. Kaplan Meier

Berdasarkan gambar I, dapat dilihat bahwa pada hari ke-I dan hari ke-3 menunjukkan kelompok perlakuan mengalami penurunan intensitas batuk terutama pada hari ke 3 setelah di berikan terapi vitamin D. Hal tersebut bisa dilihat pada garis berwarna hijau yang merupakan penanda kelompok perlakuan (vitamin D) berada di bawah garis berwarna biru (plasebo). Hasil ini menjelaskan bahwa vitamin D mampu memberikan perbaikan klinis batuk yang lebih cepat daripada pasien yang tidak mendapatkan terapi vitamin D.

Hasil penelitian ini di dukung oleh hasil Penelitian prospective observational yang dilakukan oleh Özdemir et al. (2016) menjelaskan tentang hubungan antara level vitamin D $(25(\mathrm{OH})-\mathrm{D})$ pada pasien anak yang mengalami infeksi pernafasan dan batuk kronik. Hasil penelitian tersebut terdapat perbedaan yang bermakna $(p<0,05)$ terhadap tingkat perbedaan serum $25(\mathrm{OH})$, dimana pasien yang memiliki serum $25(\mathrm{OH})$ D di bawah normal, mengalami peningkatan frekuensi batuk kronis. Kekurangan vitamin D pada pasien anak yang mengalami infeksi pernafasan meningkatkan angka kekambuhan infeksi pada pernafasan dan batuk kronik. Hasil penelitian ini berbeda dengan hasil penelitian yang dilakukan oleh Laaksi et al. (2010) di Finlandia pada pasien pneumonia usia 18-28 tahun menunjukkan tidak terdapat perbedaan bermakna antara kelompok perlakuan (vitamin D) dengan kelompok plasebo $(p=0,303)$ dalam perbaikan klinis batuk. Hal ini bisa saja 
di sebabkan oleh perbedaan subjek usia yang dilakukan dalam penelitian ini.

Penelitian yang dilakukan oleh Jolliffe et al. (2013) menunjukkan adanya korelasi antara hubungan kadar vitamin $D$ dalam darah dengan infeksi saluran pernafasan dimana pada kondisi kadar vitamin D dalam darah rendah, akan meningkatkan resiko terjadinya infeksi. Korelasi lainnya juga di jelaskan oleh (Olliver et al., 2013) menjelaskan bahwa suplemen vitamin D dapat mengurangi gejala infeksi saluran pernapasan serta konsumsi antibiotik di antara pasien dengan defisiensi antibodi.

\section{KESIMPULAN}

Pemberian vitamin $D$ sebagai terapi tambahan efektif dalam mempercepat penurunan frekuensi batuk pasien anak yang terinfeksi pneumonia.

\section{UCAPAN TERIMA KASIH}

Penulis mengucapkan banyak terimakasih kepada pasien dan keluarga pasien (responden), dokter, apoteker, perawat dan pihak-pihak yang terkait yang ada di Rumah Sakit Muhammadyah Bantul yang sudah membantu dan memfasilitasi peneliti hingga peneliti menyelesaikan penelitian ini tanpa kendala. Peneliti juga mengucapkan banyak terimakasih kepada Tim Task Force yang telah membantu membiayai publikasi penelitian ini pada Program Kompetisi Kampus Merdeka (PKKM).

\section{REFERENSI}

I. Dahlan Z. Pneumonia. In Setiati S, Alwi I, Sudoyo AW, Simadibrata M, Setyohadi B, Syam Af (Eds). Buku Ajar Ilmu Penyakit Dalam. $6^{\text {th }}$ ed. Jakarta: Pusat Penerbitan Ilmu Penyakit Dalam FKUI; 2014.pl608-19

2. World Health Organization (20I7). Pneumonia. Geneva, World Health Organization
3. Riset Kesehatan Dasar (Riskesdas). 20I3. Jakarta: Badan Penelitian dan Pengembangan Kesehatan, Departemen Kesehatan, Republik Indonesia

4. Unicef, 2017. Pneumonia claims the lives of the world's most vulnerable children, https://data.unicef.org/topic/child-

health/pneumonia/, Diakses pada tanggal 22 Februari 2020

5. Rudan, I., Boschi-Pinto, C., Biloglav, Z., Mulholland, K., \& Campbell, H. (2008). Epidemiology and etiology of childhood pneumonia. Bulletin of the World Health Organization, 86(5), 408-4I6.

6. Riset Kesehatan Dasar (Riskesdas). 2007. Jakarta: Badan Penelitian dan Pengembangan Kesehatan, Departemen Kesehatan, Republik Indonesia

7. Kemenkes RI. (2017). Profile Kesehatan Indonesia Tahun 2017. Ministry of Health Indonesia, I-276.

8. Dinkes Bantul. (2017). Profil Kesehatan Kabupaten Bantul Tahun 2017. Dinas Kesehatan Kabupaten Bantul.

9. Feldman D, Krishan AV, Swami S et al. 2014. The role of vitamin $D$ in reducing cancer risk and progression. Nature Cancer; 14: 342-57

10. Sankar, J., Lotha, W., Ismail, J., Anubhuti, C., Meena, R. S., \& Sankar, M. J. (20I6). Vitamin D deficiency and length of pediatric intensive care unit stay: a prospective observational study. Annals of Intensive Care, 6(I), I-9.

II. Dungel, A. Alam, M,S., (20I5). Efficacy of vitamin $D$ in children with pneumonia: a randomized control trial study.

12. Kaunang, T. C., Runtunuwu, L. A., and Wahani, M. A., 2016, Gambaran karakteristik pneumonia pada anak yang dirawat di ruang perawatan intensif anak RSUP Prof. Dr. R. D. Kandou Manado periode 2013 20I5, Jurnal e-Clinic (eCl), 4 (2), Juli-Desember 2016.

13. Özdemir, B., Köksal, B. T., Karakaș, N. M., Tekindal, M. A., \& Özbek, Ö. Y. (20I6). Serum Vitamin D Levels in Children with Recurrent Respiratory Infections and Chronic Cough. Indian Journal of Pediatrics, 83(8), 777-782.

14. Laaksi, I., Ruohola, J., Mattila, V., Auvinen, A., Ylikomi, T., \& Pihlajamäki, H. (20l0). Vitamin D Supplementation for the Prevention of Acute Respiratory Tract Infection: A Randomized, 
Double-Blinded Trial among Young Finnish Men. The Journal of Infectious Diseases, 202(5), 809-814. https://doi.org/10.1086/654881

15. Jolliffe, D. A., Griffiths, C. J., \& Martineau, A. R. (20I3). Vitamin $D$ in the prevention of acute respiratory infection: Systematic review of clinical studies. Journal of Steroid Biochemistry and Molecular Biology, 136(I), $321-329$.

https://doi.org/10.1016/j.jsbmb.2012.11.017

16. Olliver, M., Spelmink, L., Hiew, J., Meyer-Hoffert, U., Henriques-Normark, B., \& Bergman, P. (20I3). Immunomodulatory effects of vitamin $D$ on innate and adaptive immune responses to Streptococcus pneumoniae. Journal of Infectious Diseases, 208(9), |474-|48|. 